Konservasi Hayati, 17 (1): 1-9, April (2021)

https://ejournal.unib.ac.id/index.php/hayati/

p-ISSN: 0216-9487

email:konservasihayati@unib.ac.id

e-ISSN: 2722-1113

\title{
KEBERADAAN Desmanthus virgatus (L.) Willd. (Fabaceae) MELIAR DI PULAU JAWA
}

\section{Arieh Mountara ${ }^{1 *}$, Arifin Surya Dwipa Irsyam ${ }^{2}$, Muhammad Rifqi Hariri ${ }^{3}$, Zakaria Al Anshori ${ }^{4}$, Dini Andari ${ }^{5}$}

\author{
${ }^{1}$ Forum Pohon Langka Indonesia (FPLI), Gedung Kusnoto, J1. Ir. H. Juanda No. 18, Bogor \\ ${ }^{2}$ Herbarium Bandungense (FIPIA), Sekolah Ilmu dan Teknologi Hayati (SITH), Institut Teknologi \\ Bandung, Labtek VC, Jl. Let. Jen. Purn. Dr (HC) Mashudi No. 1, Sumedang \\ ${ }^{3}$ Pusat Penelitian Konservasi Tumbuhan dan Kebun Raya, Lembaga Ilmu Pengetahuan Indonesia, Jl. \\ Ir. H. Juanda No. 13, Bogor \\ ${ }^{4}$ Laboratorium Ekologi Hutan, Departemen Silvikultur, Fakultas Kehutanan, Institut Pertanian Bogor, \\ Dramaga, Bogor \\ ${ }^{5}$ Indonesian Genetic and Biodiversity Community (IGBC), Jl. Ikan Mujair No. 15, Kelurahan Tunjung \\ Sekar, Lowokwaru, Malang \\ *corresponding author : ariehmountara@gmail.com
}

\begin{abstract}
Desmanthus virgatus (L.) Willd. is native to Tropical America and reported present in Dutch East Indies in 1855. Nonetheless, the existence of its wild population is yet to be known, which caused by lack of record in Flora of Java vol. I. Hence the research conducted to report the existence of Desmanthus virgatus in Java. The research also conducted as a part of Alien Flora of Java compilation project. Field observation conducted in West Java (Bandung, Bekasi, Bogor, Sumedang) and Central Java (Batang) by using the explorative method. Field observation results showed the existence of Desmanthus virgatus wild population in Bekasi, Sumedang, and Batang. Therefore, the species can be stated as a new record of alien species for Flora of Java. Desmanthus virgatus presumably already escaped from cultivation and able to form its wild population in the nature.
\end{abstract}

Keywords: Alien species, Desmanthus, Fabaceae, Java, Legume

\begin{abstract}
ABSTRAK
Desmanthus virgatus (L.) Willd. merupakan tumbuhan asing dari Amerika Tropis dan telah dilaporkan tumbuh di Hindia Belanda pada tahun 1855. Meskipun demikian, keberadaan populasi meliarnya di Pulau Jawa belum diketahui secara pasti, karena belum tercatat dalam Flora of Java jilid I. Oleh sebab itu, penelitian ini dilakukan untuk melaporkan keberadaan Desmanthus virgatus di Jawa. Penelitian ini juga dilakukan sebagai bagian dari penyusunan buku Alien Flora of Java. Pengamatan lapangan telah dilakukan di Jawa Barat (Bandung, Bekasi, Bogor, Sumedang) dan Jawa Tengah (Batang) menggunakan metode jelajah. Hasil pengamatan menunjukkan adanya populasi meliar Desmanthus virgatus di Bekasi, Sumedang, dan Batang. Oleh karena itu, jenis ini dapat ditetapkan sebagai tumbuhan asing rekaman baru untuk informasi Flora Jawa. Desmanthus virgatus diduga telah lolos dari kultivasi dan mampu membentuk populasi meliarnya di alam.
\end{abstract}

Kata Kunci: Desmanthus, Fabaceae, Jawa, Jenis asing, Polong 


\section{PENDAHULUAN}

Fabaceae merupakan satu dari tiga suku tumbuhan berbunga dengan jumlah anggota terbesar. Suku ini memiliki anggota mencapai 18.000 jenis yang termasuk ke dalam 650 marga dengan ciri umum berupa buah bertipe polong (Shugang et al., 2010; Simpson, 2010; APG IV, 2016). Pada sistem klasifikasi sebelumnya, suku Fabaceae dibagi menjadi tiga anak suku, yakni Caesalpinioideae, Faboideae, dan Mimosoideae (Simpson, 2010). Namun, hasil analisis sekuen DNA yang dipadukan dengan perbandingan ciri morfologi terkini, secara lebih lanjut anggota suku Fabaceae dibagi ke dalam enam anak suku yang terdiri dari Caesalpinioideae, Cercidoideae, Detarioideae, Dialioideae, Duparquetioideae, dan Faboideae (LPWG, 2017).

Anggota suku Fabaceae memiliki distribusi yang cukup luas karena dapat ditemukan hampir di seluruh belahan dunia (Shugang et al., 2010). Informasi mengenai jenis-jenis Fabaceae di kawasan Malesia hingga saat ini telah dihimpun di dalam dua bagian buku Flora Malesiana, yakni jilid 11 (Mimosoideae) dan 12 (Caesalpinioideae). Sementara itu, informasi jenis tumbuhan polong di Pulau Jawa telah terangkum dalam Flora of Java jilid pertama (Backer \& Bakhuizen van den Brink, 1963).

Suku Fabaceae selain bersifat kosmopolit karena memiliki distribusi yang luas, juga menunjukkan kemampuan adaptasi yang baik. Beberapa jenis tumbuhan polong eksotik telah diketahui tumbuh meliar, ternaturalisasi, dan menjadi gulma di Pulau Jawa. Beberapa di antaranya yakni Aeschynomene americana L., Centrosema pubescens Benth., Crotalaria pallida Aiton, Crotalaria retusa L., Mimosa invisa Colla, Mimosa pudica L., dan Tephrosia purpurea (L.) Pers. (Hariri \& Irsyam, 2019). Sebagian jenis lainnya bahkan telah ditetapkan sebagai tumbuhan asing invasif yang penting di Indonesia, seperti Acacia decurrens Willd., Leucaena leucocephala (Lam.) de Wit, dan Calliandra houstoniana var. calothyrsus (Meisn.) Barneby (Tjitrosoedirdjo et al., 2016).
Jumlah jenis tumbuhan asing akan terus bertambah di Jawa, sehingga perlu dilakukan suatu kajian khusus mengenai kelompok tumbuhan tersebut. Salah satu temuan terkini yaitu keberadaan Desmanthus virgatus yang tumbuh meliar pada beberapa lokasi di pulau Jawa. Informasi mengenai populasi meliarnya di Jawa belum tercatat dalam Flora of Java maupun Flora Malesiana jilid 11, namun suatu spesimen herbarium menunjukkan bahwa jenis ini pernah tercatat sebagai koleksi hidup di Kebun Raya Bogor. Temuan ini menunjukkan bahwa studi dan kondisi meliarnya $D$. virgatus perlu dilaporkan, sekaligus melengkapi bagian dari penyusunan buku Alien Flora of Java.

\section{METODE}

Penelitian dilakukan pada bulan September 2020 di Jawa Barat (Bandung, Bogor, dan Sumedang) dan Jawa Tengah (Batang). Sementara itu, pengamatan di Desa Segarajaya, Bekasi, Jawa Barat, telah dilakukan sebelumnya pada bulan September 2019. Eksplorasi lapangan dilakukan menggunakan metode jelajah (Rugayah et al., 2004), sementara pengambilan material tumbuhan di lapangan mengikuti van Balgooy (1987). Material tumbuhan yang telah dikoleksi kemudian diawetkan menjadi spesimen herbarium mengikuti Djarwaningsih et al. (2002) di Herbarium Bandungense (FIPIA), Sekolah Ilmu dan Teknologi Hayati, Institut Teknologi Bandung.

Identifikasi spesimen mengacu pada beberapa referensi, yakni Flora of Australia Vol. 12 (Cowan, 1998), Flora del Valle de Tehuacán-Cuicatlán (Grether et al., 2006), Flora Guatemala Vol. 24 (5) (Standley \& Steyermark, 1946), Flora Malesiana Ser. 1, Vol. 11(1) (Nielsen, 1992), Flora van Nederlandsch Indie Vol. 1 (1) (Miquel, 1855), Flora Vitiensis nova Vol. 3 (Smith, 1985), dan Monograph of Desmanthus (LeguminosaeMimosoideae) (Luckow, 1993). Pengecekan spesimen herbarium untuk mencocokkan deskripsi dan keberadaan objek penelitian di Indonesia dilakukan di Herbarium Bogoriense (BO). Terminologi yang dilakukan dalam 
penulisan deskripsi mengacu pada Rifai dan Puryadi (2008).

\section{HASIL DAN PEMBAHASAN Perlakuan Taksonomi}

Desmanthus virgatus (L.) Willd., Sp. Pl. 4, 4: 1047 (1806); Miquel, Fl. Ned. Ind. 1: 44 (1855); Nielsen, Fl. Males. Ser. 1, 11(1): 213 (1992); Cowan, Fl. Austr. 12: 20 (1998); Acacia virgata (L.) Gaertn., Fruct. Sem. Pl. 2: 317 (1791); Acuan virgatum (L.) Medik., Theodora 62 (1786). - Mimosa virgata L., Sp. Pl. 1: 519 (1753). Tipe: "in India", Herb. Linnaeus 1228.13 (holo LINN). (Gambar 1). Desmanthus depressus Humboldt \& Bonpland ex Willdenow, Sp. pl. 4: 1046 (1806); Mimosa depressa (Humboldt \& Bonpland ex Willdenow) Poiret, Encycl. suppl. 1: 58 (1810). Acuan depressum (Humboldt \& Bonpland ex Willdenow) Kuntze, Revis. gen. pl. 1: 158 (1891); Desmanthus virgatus var. depressus (Humboldt \& Bonpland ex Willdenow) B. L. Turner, Field \& Lab. 18(2): 61 (1950). Tipe: in America Meridionali [South America], Humboldt \& Bonpland 3755 (holo B).

Desmanthus tenellus DC., Prodr. 2: 445 (1825). Tipe: "in Indiae orient.," Anon. s.n. (holo G-DC).

Desmanthus pratorum Macfadyen, Fl. Jamaica 1: 311 (1837). Tipe: Jamaica, Oxford pastures, St. Thomas in the East (holo ?).

Acuan texanum Britton \& Rose, N. Amer. Fl. 23: 136 (1928). Tipe: U.S.A. Texas: Pierce, 16 Sep 1901, Tracy 7786 (holo NY; iso: US).

Acuan tracyi Britton \& Rose, N. Amer. Fl. 23: 135 (1928). Tipe: U.S.A. Texas: Pierce, 16 Sep 1901, Tracy $7786 a$ (holo NY).

Perdu, menyelusur, mendongak, atau jarang tegak, tinggi hingga $40 \mathrm{~cm}$. Batang bersegi, tidak beronak, panjang ruas $2,5-3,5 \mathrm{~cm}$, gundul, hijau kecokelatan; daun penumpu membenang, panjang 2-4 $\mathrm{mm}$, berkanjang. Daun majemuk menyirip ganda, berseling; kelenjar nektar ekstrafloral bulat telur atau mencakram, besar, duduk, lebar 0,5-1 mm, merah; tangkai daun 3-7 mm, hijau kecokelatan; pinak daun primer 5-6 pasang, berhadapan; tangkai pinak daun primer panjang 1-2 $\mathrm{mm}$; rakis panjang 2-4 $\mathrm{mm}$; pinak daun sekunder 13- 24 pasang, berhadapan, memita hingga melanset-memita, 1,5-3 $\times 0,5-1 \mathrm{~mm}$, pangkal menyerong, tepi rata, ujung bertusuk. Perbungaan bonggol, aksilar, terdiri dari 6-8 helai bunga; gagang perbungaan 1,7-2 cm, hijau, gundul; daun kelopak berlekatan, memangkuk, bercuping 5, panjang c. $2 \mathrm{~mm}$, hijau kemerahan; daun mahkota berlepasan, 5 helai, melanset sungsang, panjang c. $4 \mathrm{~mm}$, hijau pucat dengan bagian ujung kemerahan atau keunguan; benang sari 10 helai; tangkai sari membenang, panjang $c .7 \mathrm{~mm}$, putih; kepala sari melonjong, panjang $c .0,5 \mathrm{~mm}$, kuning, tidak berkelenjar; putik 1; bakal buah menumpang, memita. Buah polong, 1-4 per bonggol, tegak pada gagang perbungaan, bentuk memita, 5-7,5 $\times 0,3-0,4 \mathrm{~cm}$, melengkung, pipih, cokelat kemerahan mengilap, bersekat 19-23. Biji segi empat hingga bulat telur, $3-4 \times 2,5-3 \mathrm{~mm}$, pipih, cokelat; pleurogram membentuk huruf $U$ hingga berbentuk bulan sabit, simetris.

Distribusi: Desmanthus virgatus tersebar secara alami di Amerika Tropis (Nielsen, 1992). Area sebaran alaminya mencakup Texas dan Florida (USA), bagian timur dan selatan Meksiko, Amerika Tengah, Kepulauan Karibia, dan Amerika Selatan (Luckow, 1993). Saat ini telah ternaturalisasi di beberapa wilayah tropika termasuk di Sulawesi (Indonesia) dan Kepulauan Pasifik (Kaledonia Baru) (Pengelly \& Topark-Ngarm, 1992). Di Australia tercatat di Timber Creek sebelah utara Darwin, Maningrida, daerah pesisir Qld sekitar Rockhampton, Brisbane, dan Roma (Cowan, 1998).

Habitat: Tumbuh pada area yang terlantar seperti jalur kereta api, padang rumput, tepi jalan, area jalanan urban, semak belukar area pesisir dan pantai berpasir, tepian formasi mangrove, dan batas area deposit garam (Luckow, 1993; Cowan, 1998). Secara umum jenis ini berasosiasi dengan tanah liat atau liatlempung dengan kondisi netral sampai alkalin dengan rentang curah hujan antara 250-2500 mm dan ketinggian 0-2000 m dpl (Pengelly \& Topark-Ngarm, 1992). Pada lokasi pengamatan, jenis ini tumbuh di tepi jalan, kebun, dan lahan marginal. 
Spesimen yang diamati: JAWA BARAT. PT PJB UP Muara Tawar Power Plant, Desa Segarajaya, Kecamatan Tarumajaya, Bekasi, 28 September 2019, Zakaria Al Anshori PJBMTW0919-005 (FIPIA); Bukit Panorama Jatinangor, Desa Cinanjung, Kecamatan Tanjungsari, Kabupaten Sumedang, 26 September 2020, ASD Irsyam \& A Mountara
14 (FIPIA); Jogging track, Kampus ITB Jatinangor, Kecamatan Jatinangor, Kabupaten Sumedang, 27 September 2020, ASD Irsyam \& A Mountara 15 (FIPIA). JAWA TENGAH. Desa Ujungnegoro, Kandeman, Batang, 3 September 2020, D Andari \& Suroso s.n. (FIPIA).

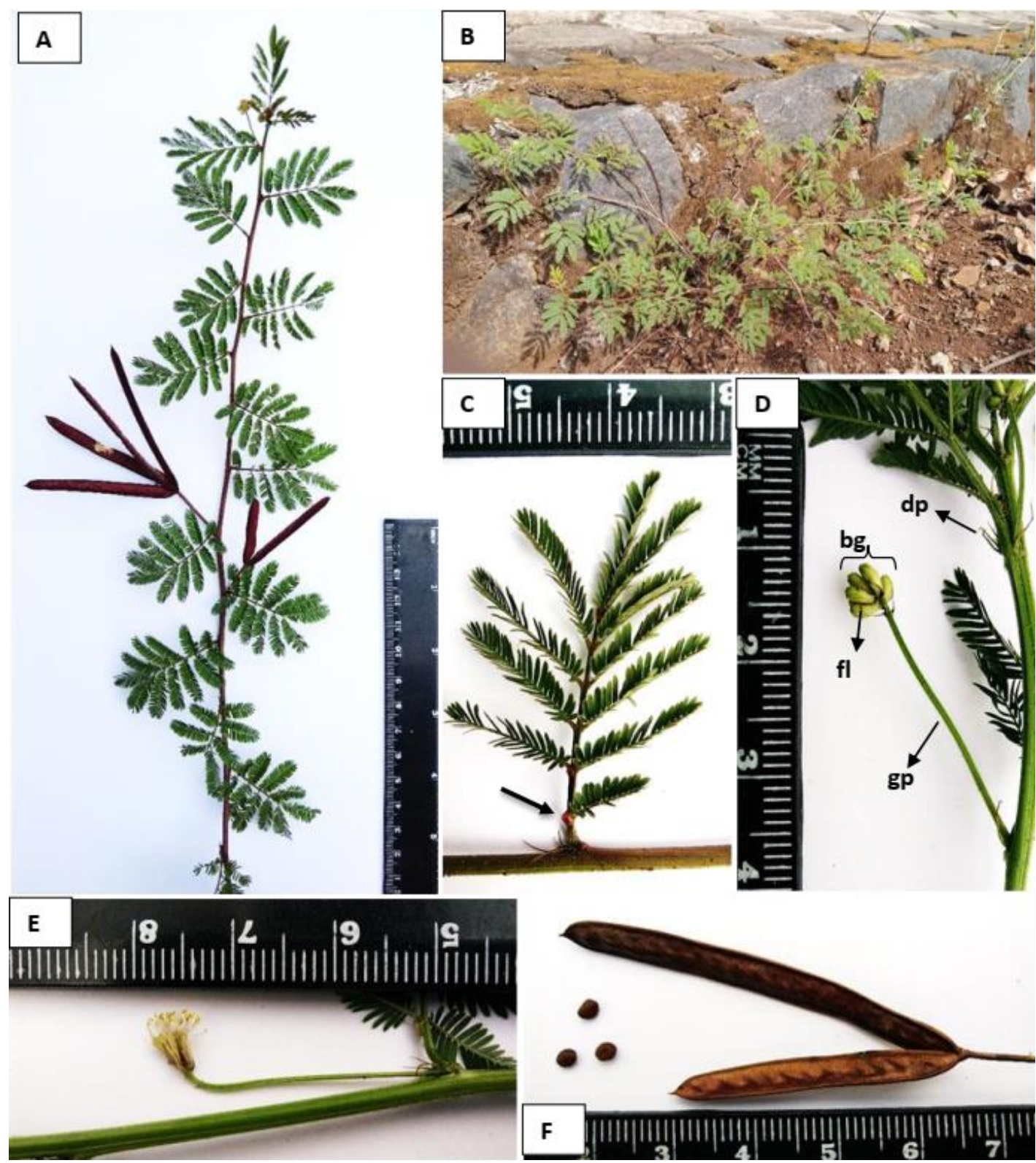

Gambar 1. Desmanthus virgatus (L.) Willd. (A) Ranting berbunga dan berbuah; (B) Perawakan; (C) Penampang satu helai daun majemuk menyirip ganda yang memperlihatkan kelenjar nektar ekstrafloral (panah); (D) Kuncup perbungaan $(\mathrm{dp}=$ daun penumpu, $\mathrm{gp}=$ gagang perbungaan, $\mathrm{bg}=$ satu perbungaan bonggol, $\mathrm{fl}=$ satu helai bunga); € Perbungaan mekar; (F) Buah dan biji 

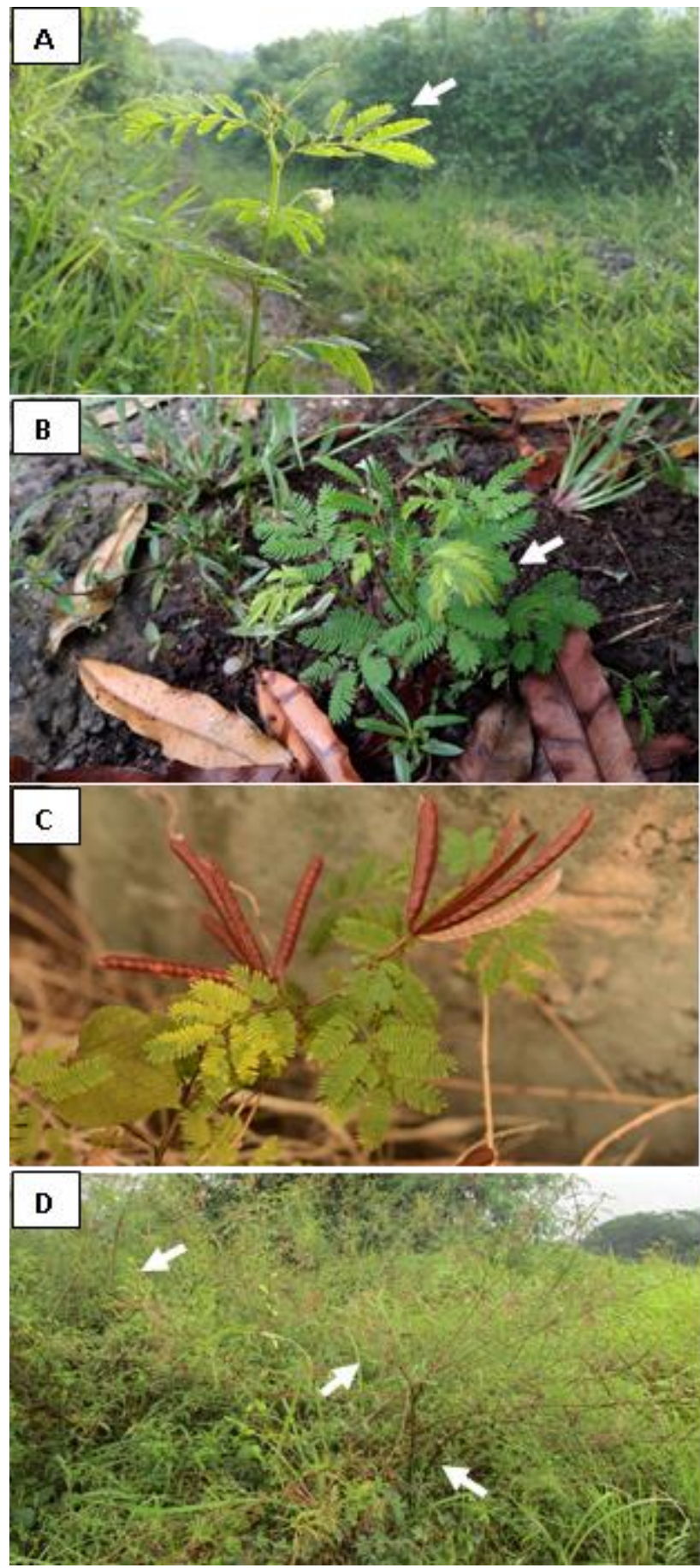

Gambar 2. Desmanthus virgatus yang tumbuh meliar di lokasi pengamatan, (A) Lahan marginal (Bukit Panorama Jatinangor, Tanjungsari); (B) Tepi jalur pedestrian (Kampus ITB Jatinangor); (C) Lahan marginal (Desa Segarajaya, Bekasi); (D) Kebun (Desa Ujungnegoro, Batang)

Desmanthus virgatus berasal dari kawasan Amerika Tropis dan tersebar mulai dari Meksiko, Amerika Tengah, Karibia, hingga Amerika Selatan (Nielsen, 1992; Luckow, 1993; Cowan, 1998). Jenis ini kemudian banyak diintroduksi ke kawasan tropis lainnya sebagai tumbuhan penutup tanah dan pakan ternak (Nielsen, 1992; Cowan, 1998; van Wyk, 2019). Jenis tersebut mampu membentuk populasi yang mapan dan menghasilkan anakan yang banyak, sehingga dapat tumbuh meliar pada lahan pertanian (National Research Council, 1979). Desmanthus virgatus telah dilaporkan ternaturalisasi di Afrika Selatan (van Wyk, 2019), Australia (Cowan, 1998; Hosking et al., 2007), Louisiana (Macroberts \& Macroberts, 2011), Singapura (Chong et al., 2009), Taiwan (Wu et al., 2003), dan Pulau Sulawesi (Pengelly \& Topark-Ngarm, 1992; Rahmita et al., 2019). Selain itu, D. virgatus juga ditetapkan sebagai salah satu jenis tumbuhan asing invasif di Jepang (Mito \& Uesugi, 2004), Palau (Space et al., 2009), dan Republik Kiribati (Space \& Imada, 2004).

Keberadaan D. virgatus di Hindia Belanda pertama kali dicatat pada tahun 1855 oleh Miquel dalam buku Flora van Nederlandsch Indie. Jenis tersebut ditulis sebagai tumbuhan yang umum dijumpai di Hindia Belanda (Miquel, 1855). Namun, daerah sebarannya tidak disebutkan secara rinci, sehingga informasinya menjadi kurang jelas. Rekaman tertua spesimen $D$. virgatus di Jawa berasal dari Kebun Raya Bogor. Spesimen tersebut dikoleksi pada tanggal 23 Juni 1897 oleh Hjalmar Möller dan saat ini disimpan di Lund Botanical Museum (LD) (Wittzell \& Shah, 2020). Selain itu, rekamannya di Jawa juga dapat diketahui dari catatan koleksi hidup Kebun Raya Bogor tahun 1855, 1866, dan 1914 (Binnendijk \& Teysmann, 1855; Binnendijk \& Teysmann, 1866; Boldingh, 1914). Meskipun demikian, D. virgatus tidak dimasukkan ke dalam daftar jenis Mimosaceae di Jawa pada Flora of Java jilid pertama oleh C.A. Backer (Backer \& Bakhuizen van den Brink, 1963).

Desmanthus virgatus ditanam sebagai tanaman percobaan di Jonggol pada tahun 1989 (Gardiner \& Burt, 1995). Enam tahun kemudian, jenis tersebut ditemukan tumbuh secara spontan di luar area plot tanamnya (Gardiner \& Burt, 1995). Jenis ini selanjutnya diduga berhasil lolos dari kultivasi dan 
menyebar lebih luas lagi. Meskipun demikian, informasi mengenai adanya populasi meliar $D$. virgatus di Pulau Jawa masih belum diketahui secara jelas. Keberadaan populasi meliarnya di Jawa baru terkonfirmasi melalui penelitian ini.

Berdasarkan hasil pengamatan lapangan, keberadaan populasi meliar $D$. virgatus pertama kali direkam dari Desa Segarajaya, Kecamatan Tarumajaya, Bekasi, pada tanggal 28 September 2019. Pada lokasi tersebut, D. virgatus ditemukan di dalam kawasan PT PJB UP Muara Tawar dan tumbuh di sekitar tepian tambak. Sementara itu, keberadaan populasi meliar $D$. virgatus di Jatinangor dan Desa Cinanjung-Tanjungsari (Kabupaten Sumedang, Jawa Barat), serta Desa Ujungnegoro (Kabupaten Batang, Jawa Tengah) direkam pada tahun 2020. Foto $D$. virgatus meliar dari masing-masing lokasi pengamatan ditunjukkan dalam Gambar 2.

Desmanthus virgatus tumbuh meliar di sekitar kebun masyarakat, tepi jalan, tepian tambak, dan lahan marginal. Penelitian terdahulu menunjukkan bahwa jenis ini tumbuh di kawasan-kawasan yang terganggu, seperti lahan terbuka, lahan peternakan, tepi jalan, dan daerah sekitar pantai pada ketinggian 0-1900 m dpl (Luckow, 1993; Cowan, 1998; Macroberts \& Macroberts, 2011).

Desmanthus virgatus sering dimanfaatkan sebagai pakan ternak (Cowan, 1998), sehingga pemencaran bijinya diduga dibantu oleh mamalia. Dugaan tersebut didukung oleh penelitian Gardiner et al. (2012) bahwa bijinya memiliki resistensi tehadap proses pencernaan hewan. Biji yang keluar bersama feses hewan ternak masih mampu berkecambah dengan viabilitas hingga 60\% (Gardiner et al., 2012). Selain itu, biji $D$. virgatus juga dapat memencar secara autokori, karena buah polongnya yang sudah masak dan kering akan pecah serta melontarkan biji (Howe \& Smallwood, 1992). Pada lokasi pengamatan di Kampus ITB Jatinangor dan Desa Cinanjung, D. virgatus tumbuh di sepanjang jalur pejalan kaki. Oleh sebab itu, bijinya diduga juga dapat memencar secara tidak sengaja karena mengontaminasi tanah yang terpijak manusia.
Secara morfologi, marga Desmanthus Willd. sepintas mirip dengan Mimosa L. Akan tetapi, kedua marga tersebut dapat dibedakan berdasarkan ciri pada organ vegetatif dan generatifnya. Perbandingan ciri morfologi keduanya ditampilkan pada Tabel 1 .

Tabel 1. Perbandingan ciri morfologi marga Desmanthus dan Mimosa

\begin{tabular}{lll}
\hline \multicolumn{1}{c}{ Ciri morfologi } & \multicolumn{1}{c}{ Desmanthus } & \multicolumn{1}{c}{ Mimosa } \\
\hline $\begin{array}{l}\text { Duri pada } \\
\text { batang }\end{array}$ & Tidak ada & $\begin{array}{l}\text { Ada atau tidak } \\
\text { ada }\end{array}$ \\
$\begin{array}{l}\text { Kelenjar nektar } \\
\text { ekstrafloral pada } \\
\text { daun }\end{array}$ & Ada & Tidak ada \\
$\begin{array}{l}\text { Daun penumpu } \\
\text { berbentuk duri }\end{array}$ & Tidak ada & Ada \\
$\begin{array}{l}\text { Perlekatan daun } \\
\text { mahkota bunga }\end{array}$ & $\begin{array}{l}\text { Saling } \\
\text { berlepasan }\end{array}$ & $\begin{array}{l}\text { Saling } \\
\text { berlekatan }\end{array}$ \\
$\begin{array}{l}\text { Buah polong } \\
\text { Membengang }\end{array}$ & $\begin{array}{l}\text { Membengang } \\
\text { per segmen buah }\end{array}$ \\
& $\begin{array}{l}\text { secara } \\
\text { menyeluruh }\end{array}$ & \\
$\begin{array}{l}\text { Permukaan buah } \\
\text { polong }\end{array}$ & Licin & Berambut sikat \\
\hline
\end{tabular}

\section{PENUTUP}

Desmanthus virgatus merupakan salah satu jenis tumbuhan asing yang belum terdaftar dalam Flora of Java vol.1. Keberadaan populasi meliarnya di Jawa belum pernah dilaporkan oleh peneliti terdahulu. Populasi meliar D. virgatus telah ditemukan dari Jawa Barat (Bekasi dan Sumedang) dan Jawa Tengah (Batang).

\section{UCAPAN TERIMA KASIH}

Penulis mengucapkan terima kasih kepada PT PJB UP Muara Tawar, Bekasi, Jawa Barat, yang telah mengizinkan pengoleksian material tumbuhan. Terima kasih juga diucapkan kepada Asih Perwita Dewi, Pusat Penelitian Biologi-LIPI, atas bantuan yang telah diberikan dalam pengecekan spesimen herbarium di Herbarium Bogoriense serta kepada Suroso yang telah membantu memberikan informasi lapangan dari Batang, Jawa Tengah. 


\section{DAFTAR PUSTAKA}

Angiosperm Phylogeny Group [APG IV]. (2016). An update of the angiosperm phylogeny group classification for the orders and families of flowering plants: APG IV. Botanical Journal of the Linnaean Society, 181: 1-20.

Backer, C.A., \& Bakhuizen van den Brink, R.C. (1963). Flora of Java (Vol. 1). Groningen, The Netherlands: WoltersNoordhoff N. V.

Binnendijk, S., \& Teysmann, J.E. (1855). Catalogus plantarum quae in Horto Botanico Bogoriensi coluntur. Batavia: Lands-Drukkerij.

Binnendijk, S., \& Teysmann J.E. (1866). Catalogus plantarum quae in Horto Botanico Bogoriensi coluntur. Batavia: Lands-Drukkerij.

Boldingh, I. (1914). Catalogus herbarii plantarum in Horto Bogoriensi cultarum. Bataviæ: Typis G. Kolff \& Co.

Chong, K.Y., Tan, H.W.T., \& Corlett, R.T. (2009). A checklist of the total vascular plant flora of Singapore: native, naturalisedand cultivated species. Singapore: Raffles Museum of Biodiversity Research, National University of Singapore.

Cowan, R.S. (1998). Mimosaceae. In A.E. Orchard (Ed.), Flora of Australia 12: Mimosaceae (excl. Acacia), Caesalpiniaceae (pp.1-49). Melbourne: ABRS/CSIRO Australia.

Djarwaningsih, T., Sunarti, S., \& Kramadibrata, K. (2002). Panduan Pengolahan dan Pengelolaan Material Herbarium serta Pengendalian Hama Terpadu di Herbarium Bogoriense. Bogor: Herbarium Bogoriense-Bidang Botani Pusat Penelitian Biologi, LIPI.

Gardiner, C., \& Burt, R.L. (1995). Perfomance characteristics of Desmanthus virgatus in contrasting tropical environtments. Tropical Grassland, 29: 183-187.
Gardiner, C., Wright, C., \& Coventry, M. (2012). The germination, passage and viability of Desmanthus virgatus (L.) Willenow seed through sheep and its implication for dispersal in tropical rangelands. In I. Yunusa (Ed.), Proceedings of the 16th ASA Conference (pp. 1-4). Armidale, Australia: Australian Society of Agronomy.

Grether, R., Martinez-Bernal, A., Luckow, M., $\&$ Zarate, S. (2006). Flora del Valle de Tehuacán-Cuicatlán Fasciculo 44: Mimosaceae Tribu Mimoseae. México: Instituto de Biologia, Universidad Nacional Autónoma de México.

Hariri, M.R., \& Irsyam, A.S.D. (2019). Jenisjenis gulma pada kebun tebu di kecamatan asembagus, situbondo, jawa timur: kelompok eudikotiledon. Jurnal Riset Biologi dan Aplikasinya, 1(2): 47-53.

Hosking, J.R., Conn, B.J., Lepschi, B.J., \& Barker, C.H. (2007). Plant species first recognised as naturalised for New South Wales in 2002 and 2003, with additional comments on species recognised as naturalised in 2000 2001. Cunninghamia, 10(1): 139-166.

Howe, H.F., \& Smallwood, J. (1992). Ecology of seed dispersal. Annual Review of Ecology and Systematics, 13: 201-228. Doi:10.1146/annurev.es.13.110182.001 221

Luckow, M. (1993). Monograph of Desmanthus (LeguminosaeMimosoideae). Systematic Botany Monographs, $\quad 38(1)$ : 1-166. Doi: $10.2307 / 25027822$

Macroberts, M.H., \& Macroberts, B.R. (2011). Desmanthus virgatus (Fabaceae): New to Louisiana. Phytoneuron, 54: 1-3.

Miquel, F.A.W. (1855). Flora van Nederlandsch Indie (Vol. 1, pt. 1). Amsterdam: C. G. van der Post.

Mito, T., \& Uesugi, T. (2004). Invasive alien species in Japan: The Status Quo and the new regulation for prevention of 
their adverse effects. Global Environmental Research, 8(2): 171191.

National Research Council. (1979). Tropical Legumes: Resources for the Future. Washington, DC: The National Academies Press.

Nielsen, I.C. (1992). Flora Malesiana: Mimosaceae (Leguminosae-

Mimosoideae) (Vol. 11, pt.1). Leiden: Rijksherbarium/Hortus Botanicus.

Pengelly, B.C., \& Topark-Ngarm, A. (1992). Desmanthus virgatus (L.) Willd. In L. 't Mannetje \& R.M. Jones (Eds.), Plant Resources of South-East Asia 4: Forages (pp. 105-106). Bogor: PROSEA Foundation.

Rahmita, Pitopang, R., \& Iqbal, M. (2019). Jenis-Jenis tumbuhan Suku Fabaceae, Subfamili Caesalpinioideae di areal Kampus Universitas Tadulako, Palu. Natural Science: Journal of Science and Technology, 8(2), 127-133. Doi: 10.22487/25411969.2019.v8.i2.13542

Rifai, M.A., \& Puryadi, D. (2008). Glosarium Biologi. Jakarta: Pusat Bahasa Departemen Pendidikan Nasional.

Rugayah, Retnowati, A., Windadri, F.I., \& Hidayat, A. (2004). Pengumpulan Data Taksonomi. In Rugayah, E.A. Widjaja, \& Praptiwi (Eds.), Pedoman Pengumpulan Data Keanekaragaman Flora (pp. 5-24). Bogor: Pusat Penelitian Biologi-LIPI.

Shugang, L., Langran, X., Dezhao, C., Xiangyun, Z., Bartholomew., B., \& Sokoloff, D.D. (2010). Flora of China: Fabaceae. (vol.10). Beijing: Science Press.

Simpson, M.G. (2010). Plant systematics. California: Elsevier Academic Press.

Smith, A.C. (1985). Flora Vitiensis nova : a new Flora of Fiji (spermatophytes only) (Vol. 3). Lawaii, Hawaii: Pacific Tropical Botanical Garden.
Space, J.C., \& Imada, C.T. (2004). Report to the Republic of Kiribati on Invasive Plant Species on the Islands of Tarawa, Abemama, Butaritari and Maiana. Honolulu, Hawaii: USDA Forest Service/Institute of Pacific Islands Forestry and Bishop Museum.

Space, J.C., Lorence, D.H., \& LaRosa, A.M. (2009). Report to the Republic of Palau: 2008 update on Invasive Plant Species. Hilo, Hawaii: U.S.D.A. Forest Service Pacific Southwest Research Station, Institute of Pacific Islands Forestry.

Standley, P.C., \& Steyermark, J.A. (1946). Flora Guatemala (Vol. 24, pt. 5). Chicago: Chicago Natural History Museum.

The Legume Phylogeny Working Group [LPWG]. (2017). A new subfamily calssification of the leguminosae based on a taxonomically comprehensive phylogeny. Taxon, 66(1): 44-77.

Tjitrosoedirdjo, S.S., Mawardi, I., \& Tjitrosoedirdjo, S. (2014). 75 Important Invasive Plant Species in Indonesia. Bogor: SEAMEO BIOTROP.

van Balgooy, M.M.J. (1987). Collecting. In E.F. de Vogel (Ed.), Manual of Herbarium Taxonomy Theory and Practice (pp.14-19). Jakarta: UNESCO.

van Wyk, B.E. (2019). The diversity and multiple uses of Southern African legumes. Australian Systematic Botany, 32: 519-546. doi: 10.1071/SB19028

Wittzell, H., \& Shah, H. (2020). Lund Botanical Museum (LD). Lund Botanical Museum (LD). Occurence dataset. https://doi.org10.15468/c4w4co diakses melalui GBIF.org https://www.gbif.org/occurence/24306 49302 
Wu, S.H., Chaw, S.M., \& Rejmanek, M. (2003). Naturalized Fabaceae (Leguminosae) species in Taiwan: the first approximation. Botanical BulletinAcademia Sinica, 44, 59-66. 